Frank Ferguson

Ulster University

\title{
Northern Soulscapes: Writing through Brexit in the Work of Gerald Dawe, Angela Graham and Dara McAnulty
}

In April 2021 rioting returned to the streets of Belfast and other areas of Northern Ireland. In a province well used to the physical and metatheatrical nature of communal violence, the burning of flashpoint security gates, known colloquially as a Peace Wall, with the inscription of Benjamin Franklin's "There never was a good war or a bad peace," seemed to sum up the failure of politics, even language in the north of Ireland at both a corporeal and metaphorical level (Walker). Analysts claimed that this rioting was due to the imposition of the Northern Ireland Protocol as part of the Brexit agreement which placed Northern Ireland within the EU trading area and imposed a sea border between it and the rest of the United Kingdom. This border was vehemently opposed by unionists and loyalists who interpreted it as derailment of the element of consent which the Good Friday Agreement/Belfast Agreement provided. This had followed weeks of speculation about economic hardship created by the Protocol and compounded unease surrounding the Coronavirus pandemic. The language of rapprochement, born out of the world generated by the Good Friday/Belfast Agreement, seemed to be lost as quickly as Franklin's words in the conflagration of brutal street politics. For many observers, the riots also represented a sickening lurch backwards into conflict, which for many who have grown up in the years after the peace was an unknown and frightening prospect. 
What possible response could literature have at this point when language, yet again, appeared to have failed? The question surfaces again as to what role can literature have to see us through the present emergency as we move from what has been described as a time of liminality and suspension in Northern Irish life to a period of fear and intimidation (Heidemann 8-9). The anxiety that creative writing and eloquence may not be enough to stave off the old atavisms returned. Questions on the viability of literature as a response to trauma that perplexed generations of Irish writers, north and south seemed to reappear. Yet some might suggest that this is not the only outcome of the current situation. While the Good Friday/Belfast Agreement heralded in much needed change for the better, it would be incorrect to claim that it has achieved universal stability, consensus and reconciliation. Enduring the uncertainty of Northern Ireland is something that its writers have long adapted to. Indeed, writers have made it their business to confront and challenge the problematic nature of Northern Irish stasis and impasse as well as hatred and sectarianism. Rather than being incapable in dealing with these situations, it could be argued that writers offer a means to comprehend the current situation in new and perhaps even in restorative ways that challenge the sense of despair that the north of Ireland is returning to its unfortunate past. In a sense Brexit and Covid are merely two more manifestations of the ever-moving conveyor belt of unease. Subsequent crises in the leadership contest of the Democratic Unionist Party, and the furore building over the British Government's stance on amnesty for the perpetrators of violence during The Troubles, demonstrate no end in sight for variations on a too well known theme. However, the capacity for coping with this ingenious and capacious political hydra is one that literature has always been apparent. The recent work of Gerald Dawe, Dara McAnulty and Angela Graham suggests that writers can provide a means to reconfigure the past and present and offer new and compelling ways to approach the future. Gerald Dawe's recent trilogy of memoirs use the term "soulscape" to capture the sense of how living in Northern Ireland may offer more to the individual and the community than a succumbing to the endemic turn to atavism. The inner perspective, refuge and alterity offered by memory and art opens access to new possibilities and a release from the ancestral antagonisms which plague the North. So how might three very different "soulscapes" deal with the spectre of Brexit, Covid-19 and renewed political tensions in Northern Ireland? The authors selected have published in the last year and represent a current flowering of Northern Irish publication. They may not engage directly to the present situation of Brexit or Covid-19 but their works are all deeply concerned with the present state of the north of Ireland. They reflect in very different ways upon the impact of the 
"peace" accorded by the Good Friday/Belfast Agreement and the wider social, economic and political conditions faced by the world in 2021.

They are part of what is a much wider collection of writers who are publishing (Smyth 50-53). A further definition of their work would be to say that they are writing through rather than writing about the current difficulties. Their ability to see things differently disrupts the old discourses of communities constricted by history and sectarianism. Despite the tensions caused by Covid and Brexit, writing and writers have endured. Indeed, the current situation affects Northern Ireland at a particularly intriguing crossroads moment where possibilities for mobility exist. However, to speak from the vantage point of now, does the proliferation and success of writers in the north of Ireland stem from the relative security of peace and albeit fractious political settlement or does it come from an opposite foundation, where writers have sought to overcome the challenge of working within a problematic state? In a sense the state was always problematical and writers have evolved a means to employ writing as a means of countering the negativity and anomie associated with Northern Ireland. Indeed, one could look at the instances of Covid and Brexit and question how significant they actually are in comparison to the challenges faced by the state in the last hundred years.

In a contested state the cultural sphere can operate as a means to explore and examine instability in ways that are more agile and innovative than political, social or community initiatives. It provides insight and understanding which other sections of society cannot. This essay will argue that authors engage with various crises to offer other voices and ways of determining reality. The texts that will be examined are: Gerald Dawe's Looking Through You, Angela Graham's A City Burning and Dara McAnulty's Diary of a Young Naturalist. As a collection of memoir, short story and nature diary they present a powerful and varied riposte to the supposition of a failure of literature and language to address current problems.

In Gerald Dawe's case we have a means through remembering places as part of his Northern Chronicles series. In recent years this has resulted in a trilogy that explores Dawe's biography linked with reminiscence about his native Belfast. The work, allied to his publications as a poet, has operated as a form of both an autobiographical prelude to his poetry and also an additional lyrical exposition of the poetry. Dawe's strategy for discussing the Northern Ireland of his childhood and teenage years is often one that directs the reader back and yet also away from the sense of place. Looking Through You opens with a memory that challenges the primacy of Belfast's City Hall as the ultimate urban and civic space within the Northern Irish mindset: 
But first it was The Beatles. I recall sitting on the bus home from Orangefield, my new school across town, as a solitary and temporarily liberated cow went blattering down Donegal Square, along by the front of the City Hall. (Dawe 11)

The key locations of his memories are telescopic. They are neither sentimental nor nostalgic but focus on places with significant personal musical and literary associations. These powerful associations expand the horizons and possibilities open to both speaker and reader.. Such recollections with hints of a comic urban pastoral mode provide alternative ways of remembering Belfast. The Belfast of the 1960 s, all too often depicted as coasting along on complacent austerity towards the Troubles and civic discord becomes a very different place in Dawe's imagination. The bus journey from his North Belfast home to Orangefield Boys School in the east of the city becomes a focal point for the music of the Beatles. This almost synaesthesia-like ability to connect musicians and writers to specific places leads to a new way of seeing and hearing the places. In the same manner, reminiscence of his time at school becomes linked to recollection of the writing of Sylvia Plath and also to the person who introduced his class to her work, the Northern Irish playwright and music critic Stewart Parker. Likewise, the seaside resort of Bangor becomes heavily associated with the work of Robert Lowell. The concept of the memoir's title, a reflection on the Beatles' song "I Am Looking Through You" and also a pun on the northern colloquial phrase "to see through you," as in to ignore the person that you are viewing as if they are not there, as well as identifying hidden motives takes on an added meaning in looking through something to see something else. Dawe seeks to see through the places of his past, almost in a way parallel to the concept of the autostereogram, not necessarily to ignore but to diverge and seek the particular resonance that those places have for them and how writers and musicians, can prove transformative, not merely for the sake of the individual but offers a means to recalibrate the past and the experience of a city and a province.

What Dawe is particularly interested in charting is the impact that such relationships had upon his Protestant background. The engagement with Protestantism derives not from a desire to continue or add to the ongoing Northern Irish culture war, but to rebalance some of the unfounded allegations that Dawe feels have been made against those from a Protestant background:

Often critics and journalists talk about 'Northern Protestants' as if they were dour, narrow, bigoted, unimaginative, mean, spiteful and so on. I am sure many are: as many as there are in any community in any 
place in the world. I get seriously fed up, though, with the way ordinary Protestants are represented as cultureless. It's when I think of William Bailey Chartres and the family he came from and the one that came from him, which includes my friends, and me, and their families whom I knew growing up in Belfast. (Dawe 35-36)

Such statements seek to move beyond the sticking point of claim and counter claim to provide a personal and family memory that challenges the reductionism of such views- "My belief is that poets are poets first and citizens second" (Dawe 36). His aims to desegregate culture move away from tired arguments. His Protestantism with its hunger for literature and poetry permits a quest for knowledge that is always moving away from the North Belfast of his childhood but primed to return through a sense of memory of place and memory of family, aware that " $[\mathrm{w}] \mathrm{riting}$ poems, finding the language, the forms and the voice, is difficult enough" (Dawe 37). To see is to embrace the writing of elsewhere whether that be the American modernists or French Absurdism, which then finds purchase in the way of seeing the North. This is not a case of one new tradition obliterating the past, but comprehending that memory is a palimpsest of new and old residing together. The early influence of the Northern Irish Protestantism with its Sunday Schools and Bible stories remains imprinted in the text with new cultural and ideological perspectives-" The weight of that world fascinated me-post-war, Protestant-and the dominant view of the Cave Hill, always there, like the past itself, high above us" (Dawe 57). Such imperatives stand as offering a proverbial way of comprehension.

Dawe's individualism saw many opportunities to tread unworn paths that become at times rites de passage for Northern writers. Hence his schooling, through Orangefield Boys High School and the Belfast College of Business Studies to the New University of Ulster at Coleraine as opposed to the grammar school system and Queen's University Belfast, present alternative paths to learning and a career and serve as an important reminder that the doorways to literary apprenticeship were not predicated upon single routes. Second chances and other paths towards success are suggested. What some have termed the hollowing out of Britishness in the north might be reinterpreted in Dawe's case as a turn towards mobility and movement and the ability to transcend the alleged waning of Protestant Ulster. Place functions as a reminder of family life, but also provides a past of "landscapes and interiors, unknown histories in very many ways, that slowly asserted themselves the farther away I went from them" (Dawe 77). Inherent in Dawe's remembering of his past is an awareness of the culture being one open to mobility and forward motion rather than stasis or inertia. 
In the intuition of the trajectory of a soul, Dawe also perceives the changing mores and political landscapes of Northern Ireland and the Republic. Ironically, this sense of movement provides a new sense of grounding: "with the modernising of the Irish Republic on most sexual and gender rights, leaving "official" Northern Ireland isolated and increasingly out of touch and out of date" (Dawe 83).

This attentiveness predicates itself on seeing the present for what it is, but also being capable of seeing beyond and through memory and the present circumstance. Like the speaker in his poem "The Moon Viewing Room," a poem that juxtaposes a community watching the moon landing from a Belfast bar with visiting a Kyoto moon-viewing attic room, divergent places and moments cohere and interact, offering possibilities of new alignment, insights and congruence. Language steps up and forward.

An awareness of changing morals, mores and values is apparent in Angela Graham's A City Burning. Published in 2020 during the pandemic, the title of Graham's work and its sharply focused short stories spoke of a variety of cities in flame. Set in Ireland, Wales and Italy, Graham's spiky, succinct prose comes from a burgeoning wave of new women's writing in the North. Graham demonstrates much poise as an observer in her deftly weighted prose. Not that her stories do not make uncomfortable reading at times. Like the protagonist in "Witness," her characters bear witness or become witness to unfolding revelations. If memory in Dawe's work is a conduit away from as much as back into a Northern Irish past, Graham is unflinching in returning to incidents that are traumatic, claustrophobic and uncomfortable. Her stories do not let the reader forget a variety of moods and hurt that constituted many pasts in the north. But it would be unfair to claim that A City Burning focuses purely on the negative, whether in the epiphanic moments of realisation or in the stirrings of positivity of kindling romantic or platonic attachment, Graham offers the potential of new beginnings. The spareness of her prose works very well in the exposure of the elemental thoughts of her protagonists. "The Ulster Psyche" captures the Catholic/Protestant tension experienced between as purchaser of a photograph.

Graham's adeptness at comprehending kaleidoscopic fluidity of place is matched by her utilization of the representation of water, particularly the sea, as a component of her writing. This is most apparent in "Coasteering." In this story, the central character, finding herself at a stage where her children have grown up and no longer need her, sets out to learn how to navigate the sea and rocks with a local guide. There is a great sense of possibility for the main character in "Coasteering" and of life opening out in middle age. The instructor, a man in his fifties, instils a sense of capability, providing the character with the ability to negotiate rock and sea swell: 
He was portly and easy-going. I felt a pleasant confidence in him, perhaps because he wasn't a typical coasteering pro. No sprightly young athlete, he was a dogged local man. The two of us had had three outings together. I enjoyed doing what he told me: swim, clamber, jump, crawl. It was a great way to let go of time. (Graham 108)

His language is both perfectly befitting for the north Coast setting, but also profoundly linked to the earth and water itself, an elemental force articulated through an indigenous minority language. Graham's usage of Ulster-Scots as an authentic element of the story is to be congratulated. The language is neither tokenistic nor forced upon the situation but functions as a very authentic detail of a story of reclamation of personal agency through wild swimming. It also takes on a deeper meaning of the significance of the unassuming voice of the place offering instruction and encouragement to the main character:

“Dinnae ower-think it!" Alec urged, and then repeated himself. I chose not to explain that what I was doing was savouring the moment: a woman in her element, teetering on a needle-point of rock thrust up among a jumble of black basalt that out-faced the heaving sea around us. Below me the cold-coloured water never broke into foam. It flexed and stretched and contracted. (Graham 107)

The story concludes with the instructor agreeing to take her out swimming one night to experience the spectacle of the Northern Lights and hints at a possible romance or at the very least a deepening association.

Graham may present us with rural cityscapes experiencing trauma, but counterpoint is providing with locations in nature in which characters realise the possibility of future lives and relationships. In Dara McAnulty's Diary of a Young Naturalist, one perceives a turning to nature in raw, lyrical terms. The echoing of Heaney's "Death of a Naturalist" is not coincidental in this work, and Heaney is mentioned on a couple of occasions in the diary entries. McAnulty shares Heaney's poetic gift in expression and has an incredible ability to capture the wonder of the everyday world. His honesty and determination to channel his soulscape helps the reader comprehend the pervasive impressiveness of ecosystems. He energises our appreciation for those aspects of nature that we take for granted such as dandelions and sparrows. To suggest that this is a book that eulogises the nature of Northern Ireland in a saccharine and unproblematic manner is to miss much of the thrust of the book. Unlike Heaney's subject in "Death of A Naturalist," where the natural processes of living and decay evince disgust and a turning away from the "flax dam," McAnulty is adamant in the 
need to embrace and safeguard the natural world. The book might have been called "diary of an activist," as we learn of his growing confidence to stand up for protecting the environment and finding a means to channel his rage, a combination of dealing with autism, the aftermath of bullying and a general coming to terms with living as an autistic adolescent:

Not only is our family bound together by blood, we are all autistic, all except Dad - he's the odd one out, and he's also the one we rely on to deconstruct the mysteries of not just the natural world but the human one too. Together, we make for an eccentric and chaotic bunch. We're pretty formidable, apparently. We're as close as otters, and huddled together, we make our way in the world. (McAnulty 9)

The appreciation of nature is hard won by McAnulty as so much of the basic operations of daily life, such as fitting in at school, communicating with others and even gaining a good night's sleep, prove challenging. Overbearing colours and tones even cause difficulties the muted tones and sounds of natural environments, such as Rathlin Island, off the north coast of County Antrim, offer an incredible escape and release from this distress. If McAnulty has a particular form of vision in his writing, it is a celebration of the microscopic and a way that focusing in on one thing such as "a flower, a bird, a sound, an insect" (McAnulty 34) can bring release and calm. This he finds can present a means to "keep myself together" and it is this search for stability and poise that also makes him such a gifted teacher and expounder on the natural world. His passionate engagement with the natural world manifests itself as a personal poetic coming to terms with the wonder of comprehension of the natural. The simple act of photographing a dandelion becomes both a prose poem extolling their ability to "make me feel like sunshine itself" (McAnulty 36) and to extol their role in providing sustenance for pollinating insects in spring. The singular plant that he homes in on is celebrated for being "the odd one out" and it is his awareness of being a similar odd one out in his society that lends much resonance to the book (McAnulty 37).

Like Dawe and Graham, it is the awareness of the potential of language to speak back and articulate who he is despite the problematic past of bullying and ill-treatment in the school system. This awakening to finding a language and outlet is a major theme of the book as he moves from a position of writing about plant and animal life that inspire him to express his anger at how badly the natural world has been mishandled by the generations in power. Again, his writing takes on an Heaneyesque eloquence that does not mourn so much 
the loss of innocence of the speaker compelled towards the adult world as the genocide of a species imperilled by shifts towards and intensive farming practice that takes no cognisance of the life cycle of the corncrake:

The crops were once cut late, allowing the corncrake pair to breed and raise young. This way of farming has been replaced with more intensive silage-making through spring and summer. This different seasonal rhythm conflicts with the birds-and the unthinkable happens, a life is cut short by the blades. Imagine it. Every egg cracked. (McAnulty 49)

Given the confessional nature of a diary, the prose can be harrowing reading at times as we are given access to the grief and rage that is felt about the climate catastrophe and the more personal turbulence of finding his way in the world. This search is underpinned by another unselfconscious awareness of the Irish linguistic cultural landscape. The diary incorporates a glossary at the end of the book, which works partly as a means to explain place names for those outside Northern Ireland, and partly to offer insights into the meanings within meanings. It is not an owl that he remembers his grandfather telling him about, but more importantly a scréachóg (McAnulty 77). It is a bird that "Granda" heard as a young man, but is now a rare occurrence in McAnulty's time.

There is much loss to discover in the book. This moves from a personal sense of dislocation as the family moves eastwards from Country Fermanagh to Country Down and such personal costs are increasingly placed within a global sense of desolation at the spectre of the Anthropocene which is perhaps the greatest terror that haunts McAnulty's imagination. He grapples with the question of the adequacy of writing to deal with the Anthropocene, which he sees as the most pressing issue in Irish, as well as global politics, potent enough to make Brexit, the Coronavirus and the Northern Irish situation pale wraiths in comparison. His sense that this may not be enough is tempered by a determination to rise up as an activist to at least make the effort to defeat the depredations caused by humans (McAnulty 120).

Immense anger is directed towards politicians whom he feels are keen to be seen meeting him, but are less able to provide real solutions to the crisis. Alongside this is an awareness of networks of similarly minded naturalists, scientists and writers with whom he connects in protests, projects and online. The discovery of Greta Thunberg provides a powerful hope that there may be alternative ways to challenge the intransigence of the adult population and a way in which individuals such as himself, without a powerbase and constrained by a number of personal circumstances, can make a difference (McAnulty 147-148). 
It is a profound revelation for him, and also a way in which his anger can be channelled without becoming destructive or self-defeating (McAnulty 177). The facts he offers are chilling. The inheritance he faces is of a world that has lost $60 \%$ of its wild species since 1970 (McAnulty 198-199). Alongside this is McAnulty's awareness of the mental health problems that his generation suffer from:

Is it any wonder that almost a quarter of young people are experiencing mental health difficulties? Our world is increasingly divided between attainment, materialism and self-analysis. We're at a tipping point in the relationship we have with ourselves, with each other, and our world. A world which is so intricately connected, so interdependent, so intrinsically linked. So delicate. The power struggle between huge organisations, economics, development and the species we share our planet with is growing so out of control that it's easy to become overwhelmed, depressed and disconnected. (McAnulty 198-199)

Yet for all the despair that such realisations could engender, Diary of a Young Naturalist ends on an optimistic note. Aware that he has become a custodian, he pledges to go out into the world and "weave his way" with all the difficulties that such an undertaking will have for him (McAnulty 209).

For Dawe, Graham and McAnulty to look through Northern Ireland in the lead up to and aftermath of Brexit is to affirm the power of writing to proffer hope. In Dawe's case, his Belfast memoir provides a radical way to view places, people, and history. By associating the music and literature of other places with Belfast, he offers a revitalising method of comprehending his version of Belfast as well as offering an innovative analysis of the writers and musicians which shaped his development as a writer.

He gifts us the opportunity to remember alternatively and to chip away at the graven histories for other readings. For Graham, there is a determination to return to difficult moments that many might want to forget. Her work at times is painfully commemorative, standing as a truth commission for a state that still avoids such a mechanism of redress. In her moments of decision-making, there is also redemption and epiphanic launching points for better worlds. In her soulscape, there is the provision of making new choices for her characters and perhaps even her readers. Ultimately, McAnulty posits that the problems of Brexit, coronavirus, even the long history of Northern Irish instability, profound and serious as they might be, pale into the very real imminent disaster faced by the Earth. Rather than language vanishing under these combined threats, these writers suggest that more than ever language is the last hope that humans have to reach each other in the void. 


\section{| Works Cited}

Dawe, Gerald. Looking Through You. Newbridge: Irish Academic Press, 2020. Graham, Angela. A City Burning. Bridgend: Seren Books, 2020.

McAnulty Dara. Diary of a Young Naturalist. London: Ebury, 2020.

Walker, Gail. "Opportunity Now for Leadership to Emerge in Unionism

to Embrace the Future... but Does Anyone Have the Vision?," Belfast Tele-

graph, 10 April 2021, https://tinyurl.com/nyzx6wpx.

Heidemann, Birte. Post-Agreement Northern Irish Literature Lost in a Liminal

Space?. Cham: Palgrave, 2016.

Smyth, Damian. "Fortnight and Fifty Years of Contested Writing in the North,"

Fortnight 479 (September 2020): 50-53.

\section{| Abstract}

Frank Ferguson

Northern Soulscapes: Writing through Brexit in the work of Gerald Dawe, Angela Graham and Dara McAnulty

At a time of when the global crises of pandemic and climate change could be said to offer sufficient challenges to life in the British and Irish Isles, the implementation of Brexit provides a further gargantuan difficulty. Borders, bureaucracies and belief systems dissolve like the certainty that subjects once felt to their connection to states or Unions. Or new borders and systems appear, bringing with them unwieldy new protocols and practices. Shelves empty, goods sit locked in containers; caught up in the holding pattern of another new normal of online retail inertia. Dislocation, fear and anger rise. The epicentre of the Brexit shambles can be said to be located in the ever betwixt and between location of Northern Ireland. Here with its newly imposed sea border with Great Britain and its maintenance of European Union relations with the Republic of Ireland we see a fractured and fractious society struggling as ever to come to terms with how to balance the aspiration of opposing ideologies and national ambitions with an additional level of chaos.

In a time of catastrophe what can literature do? This question, often posed during "The Troubles" has very much come back to be painfully reiterated to writers, readers and critics at a time of multiple lockdowns. However, if an examination is made of publishing in Ireland in the last couple of years, we see a buoyant press offering a number of intriguing responses to the significance and efficacy of literature to respond to the current human predicament. In this article I will examine the work of three contemporary writers, Gerald Dawe, Angela Graham, and Dara 
McAnulty. I will argue that their use of genre (memoir, short story, nature diary) provides a fresh and robust response to the chaotic present of Northern Irish political life. In their separate ways they contest the fixed, static and impermeable political echo chamber of Northern Ireland. Dawe, I contend, seeks a means through his autobiographical work to retrace time and space in the history of the province and articulate alternative ways of interpreting the past. He is able to draw sustenance and restoration from often overlooked times of possibility in his own and the wider story of Belfast. In Graham's case, I would suggest that her bold and assertive first collection of short stories provides an acerbic and raw inspection of the past but one that also provides glimpses of reconciliation and genuine hope in the face of trauma. I conclude by exploring the work of McAnulty. Ostensibly a diary that traces his engagements with nature, his book is a tour de force that reimagines Ireland as a location gripped in the ravages of the Anthropocene startlingly brought to life by a young man faced with the challenges of autism. Part memoir, part praise poem to nature, it is a remarkable coming of age non-fiction work, which along with Dawe's and Graham's writing suggests that Northern Irish literature offers a broad and brilliant retort to the current local and global calamities that we face.

Keywords: memory; Belfast; Anthropocene; The Troubles; Ulster-Scots; Brexit

\section{| Abstrakt}

Frank Ferguson

Północny pejzaż ducha. Brexit w pisarstwie Geralda Dawe’a, Angeli Graham i Dary'ego McAnulty'ego

W czasie, kiedy globalny kryzys w postaci pandemii i zmian klimatycznych już od pewnego czasu dostarcza wielu poważnych wyzwań na Wyspach Brytyjskich i Irlandzkich, wprowadzenie w życie brexitu napotyka na gigantyczne trudności. Dotychczasowe granice, biurokracja i różnice w wyznaniach rozpływają się we mgle, podobnie jak pewność, którą poddani Korony odczuwali co do związku z państwem brytyjskim oraz Unią. Pojawiają się za to nowe granice i systemy, przynosząc ze sobą nowe, nieefektywne protokoły i praktyki. Widać puste półki, a dobra konsumpcyjne zalegają w kontenerach i magazynach, uwięzione tam przez inercję „nowej normalności” w ramach handlu online. Narasta poczucie niepewności, strachu i złości. Wygląda na to, że epicentrum brexitowego chaosu zostało zlokalizowane w przestrzeni wiecznego pomiędzy - u granic Irlandii Północnej. Tutaj właśnie wprowadzono na morzu nową granicę z Wielką Brytanią, która zmienia też sposób, 
w jaki Irlandia Północna definiuje swoje stosunki z Unią Europejską i Republiką Irlandii, a jej podzielone i skonfliktowane społeczeństwo zmaga się z potrzebą zrównoważenia aspiracji ścierających się ze sobą ideologii i ambicji narodowościowych $\mathrm{z}$ brexitem jako dodatkowym czynnikiem prowadzącym do chaosu.

Co może zrobić literatura wobec katastrofy? To pytanie, pojawiające się często w czasie wojny domowej zwanej Konfliktem trzydziestoletnim (ang. The Troubles), powróciło jak bolesny refren w twórczości pisarzy i w opiniach czytelników oraz krytyków podczas kolejnych lockdownów. Przyglądając się jednak rynkowi wydawniczemu w Irlandii, dostrzeżemy wielość inicjatyw i ciekawych odpowiedzi na pytanie o znaczenie i skuteczność literatury wobec aktualnych dramatów. Artykuł przedstawia twórczość trojga pisarzy: Geralda Dawe’a, Angeli Graham i Dary’ego McAnulty'ego. Dowodzi, że wybrany przez nich gatunek (wspomnienia, opowiadanie, pamiętnik przyrodniczy) stanowi świeżą i dynamiczną reakcję na chaos politycznej codzienności w Irlandii Północnej. Na różne sposoby pisarze ci kontestują sztywny, statyczny, nieprzenikniony porządek polityczny Irlandii Północnej. Dawe, jak wynika z artykułu, szuka rozwiązań w swojej autobiografii, by odtworzyć czas i miejsca związane $\mathrm{z}$ historią prowincji i dać wyraz alternatywnym metodom interpretacji przeszłości. Czerpie energię twórczą z pomijanych i niedocenianych potencjałów swojej własnej przeszłości oraz historii Belfastu. W przypadku Graham pierwszy, śmiały zbiór opowiadań oferuje cierpki i surowy wgląd w przeszłość, jednocześnie uwzględniając akcenty pojednawcze i autentyczną nadzieję w obliczu traumy. Ostatni fragment artykułu poświęcony jest twórczości McAnulty’ego. Na pierwszy rzut oka to pamiętnik skupiający się na jego kontaktach z przyrodą, a przede wszystkim książka stanowiąca prawdziwy tour de force, w którym Irlandia jawi się jako kraina znajdująca się w destrukcyjnych kleszczach antropocenu, przedstawiona w zaskakujący sposób przez młodego człowieka zmagającego się z wyzwaniami autyzmu. Jako połączenie pamiętnika i poematu chwalącego przyrodę, praca McAnulty'ego stanowi zapis dorastania, który obok dzieł Dawe’a i Graham dowodzi, że literatura północnoirlandzka ma w zanadrzu wszechstronną $\mathrm{i}$ wnikliwą ripostę na współczesne wyzwania i nieszczęścia - zarówno lokalne, jak i globalne.

Słowa kluczowe: pamięć; Belfast; antropocen; konflikt w Irlandii Północnej; język Ulster-Scots; brexit

\section{| About the Author}

Frank Ferguson is the Research Director for English Language and Literature at Ulster University. He has over twenty years' experience as a researcher and teacher in 


\section{4 | FRANK FERGUSON}

literary studies. He has written and edited a number of significant texts on Northern Irish and Irish literature. He leads a number of ongoing academic and community projects on Irish and Ulster-Scots writing.

E-mail: f.ferguson@ulster.ac.uk

ORCID: OOOO-0003-4150-9295 